\title{
Evaluation of Training Programmes on Oyster Mushroom Cultivation Conducted by KVK, Barpeta and Constraints Perceived by Mushroom Growers in Barpeta District of Assam, India
}

\author{
G.K. Upamanya ${ }^{1}$, Haridra Sarma ${ }^{2}$, P.D. Barman ${ }^{3}$ and A.K. Deka ${ }^{3}$ \\ ${ }^{1}$ Department of Plant Pathology, SCS College of Agriculture, AAU, Dhubri, India \\ ${ }^{2}$ Department of Extension Education, B.N. College of Agriculture, \\ $A A U$, Biswanath Chariali, India \\ ${ }^{3}$ Krishi Vigyan Kendra, AAU, Barpeta, India \\ *Corresponding author
}

\section{Keywords}

Oyster mushroom,

Training,

Demonstration,

Krishi Vigyan

Kendra, Knowledge

Article Info

Accepted:

05 April 2020

Available Online:

10 May 2020

\section{A B S T R A C T}

The key role played by Krishi Vigyan Kendras (KVK) of India in popularizing oyster mushroom cultivation technology among the rural youths through training and demonstration programmes has been widely appreciated. Evaluation of outcome and efficacy of the training and demonstration programmes conducted by KVKs are necessary to keep the method of transfer of technology in right track. The present study was undertaken to find out the impact of training and demonstration programme conducted by Krishi Vigyan Kendra, Barpeta. A complete list of 300 participants was randomly prepared who had undergone the training and demonstration on oyster mushroom production from 2009-10 to 2016-17. The reasons for participating in training and demonstration programme at KVK were studied based on the stated reasons of the respondents, and found that $82.33 \%$ of the respondents were interested to know the mushroom cultivation technology for additional source of income. In another study to assess the gain in knowledge after training and demonstration programmes with 60 numbers of respondents out of listed participants, it was observed that pre-training knowledge score was not much satisfactory (50\% of the respondents had low level of knowledge). However, the knowledge score gained by respondents after training was more satisfactory in all aspects (58.33\% had medium and $48.67 \%$ had high level of knowledge). The socio economic factors of the participants viz. Education level played a significant positive role on the knowledge gain of the participants. The study on the constraints faced by the 60 numbers of adopters indicated that lack of supply of mushroom spawn was the major constraint faced by $91.67 \%$ of the adopters followed by lack of financial assistance from bank or other financial institutions for mushroom entrepreneurs (81.67\%).

\section{Introduction}

Mushroom is classed as a pleasantly flavoured low calorie and highly proteinaceous food (as high as 30\%) supplying appreciable amounts of vitamins and minerals. Today, mushrooms are accepted as health food in many parts of the world. The protein content is more than any fruit or vegetable or cereal grain and also it consists 
of all the essential amino acids and is especially rich in lysine and glutamic acid. The digestibility of mushroom protein lies between $71-90 \%$. The low calorie, high fibre content and absence of cholesterol are additional advantages of mushroom as healthy food. The flavor enhancing property of mushrooms is better known than the food value. Glutamic acid, one of the flavor enhancing components, is easily released during cooking. The oyster mushroom (Pleurotus $\mathrm{sp}$ ), a wood destroying saprophytic fungus grows under natural conditions on trees or dead woody branches. Several species of oyster mushroom can be cultivated under indoor condition without using any pesticides. High value of nutrition, medicinal properties and lack of pesticides residue in mushroom are some of the important factors which may contribute to its popularity among the health conscious consumers. In Assam, cultivation and consumption of mushroom were limited in few areas due to lack of awareness about the health benefits of this high valued food. However, with the increased number of trainings, awareness camps and demonstration programmes conducted by Krishi Vigyan Kendras (KVK), mushroom becomes popular among the people of Assam particularly the rural masses. In Barpeta district of Assam very few entrepreneurs used to cultivate oyster mushroom in a small scale due to lack of organized market. After continuous efforts of $\mathrm{KVK}$, Barpeta by conducting training, demonstration and awareness camps since 2009, the consumers and growers of oyster mushroom have increased manifold in rural and urban areas of the district. There is, however, tremendous scope for popularizing this health food among the consumers and thus encouraging the unemployed rural youths to take up oyster mushroom cultivation as a venture of self employment. In this context, it is necessary to find out the outcome and efficacy of the training and demonstration programme conducted by $\mathrm{KVK}$, Barpeta in popularizing the mushroom cultivation in the district. The present study was undertaken with the specific objectives to find out the probable reasons for participation in the training programme, knowledge gained after training and demonstration, differences in the level of knowledge gained based on socioeconomic profile of the participants and the constraints faced by the adopters of oyster mushroom cultivation technology and the ranking of the constraints as well.

\section{Materials and Methods}

The study was undertaken in the villages of Barpeta district of Assam where Front Line Demonstrations (FLDs) and training on mushroom cultivation was conducted by Krishi Vigyan Kendra, Barpeta during 200910 to 2016-17. A list of 300 beneficiaries of the aforesaid period was prepared randomly from 10 numbers of villages of 5 Development Blocks. The reasons for participating in the training and demonstration programmes were assessed by preparing and administering a close ended interview schedule. Further, from the list of 300 participants, 60 were selected following a simple random sampling method to evaluate the knowledge gained by the trainees on before and after basis. The method followed by Sarma et al., (2013) and Upamanya et al., (2019) was used to evaluate the knowledge gained by the trainees. In order to find out the distribution of the respondents according to their level of knowledge and to measure the significance of difference between the mean score of knowledge, a knowledge test was developed. While administering the final knowledge test, score ' 1 ' (one) was assigned for a correct answer and score ' 0 ' (zero) was assigned for an incorrect answer. Total number of questions to test the knowledge level of the respondent were 35 and thus, a respondent could score maximum 35. The score so obtained under various questions 
were summed up. On the basis of the total score obtained, respondents were categorized into three classes i.e. low, medium and high level of knowledge using the procedure followed by Dasgupta (1989).

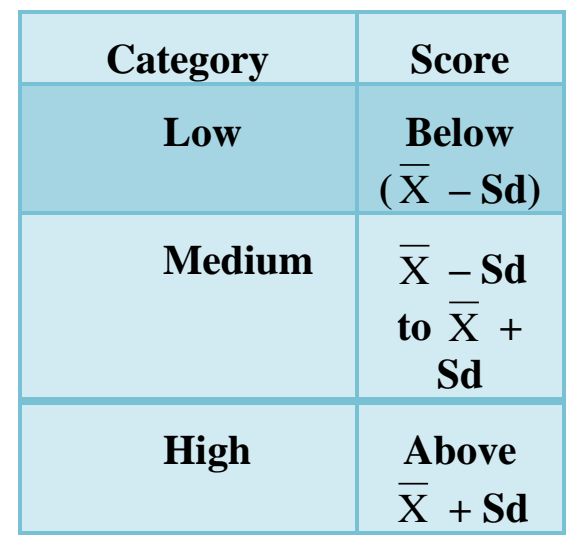

Finally, paired ' $t$ ' test was used to test the significance of differences in knowledge gained on before and after basis. The relation of a set of selected independent variables with knowledge gained was also examined. Finally, constraints faced by the mushroom growers were studied and ranked following the method developed by Singh et al., (2020).

\section{Results and Discussion}

\section{Characteristics of the respondents}

The study revealed that more than half $(56.67 \%)$ of the respondents belong to the young age group of 18 to 30 years (Table 1). Lack of employment opportunity may be one of the reasons of higher rate of participation of young age group in the training programme. Educational level of majority of respondents (33.33\%) was 'matriculate' followed by 'middle school level' (28.33\%). There were no illiterate participants in the training and demonstration programmes. It implies the importance of education in adopting modern approach of agricultural technology. The finding is in conformity with Leihaothabam et al., (2020) who observed the 0 per cent illiterate farmers in a study on training needs assessment of rice growers in Manipur, India. Farming was the prime occupation for majority $(90 \%)$ of the respondents and more than 65 per cent respondents were marginal farmers. Availability of the inputs like rice straw, firewood and limitation of land resources may be the major factors behind the attraction of marginal farmers towards mushroom enterprise (Rachna et al., 2013). The result further showed that 55 per cent of the respondents had only 1 to 5 years of experience in farming. The result indicates that the youths with minimum farming experience in traditional practices were interested towards the farming enterprise which ensures best return with minimum investment. Progressive farmers / fellow farmers (43\%) and input dealers (33.33\%) were the most commonly utilized information sources by the respondents. In this context, the major role of KVK towards popularizing mushroom cultivation is reflected. The progressive farmers in touch with KVK may be the major source of information about the training and demonstration programme (Table-1)

\section{Reasons of participation in the training on oyster mushroom cultivation}

The frequency and Percentage distribution of respondents based on their stated reasons for participating in training and demonstration programme on oyster mushroom cultivation was shown in Table 2. All the respondents $(100 \%)$ joined the training and demonstration programme to know the technology for home consumption. However, $82.33 \%$ of the respondents were interested to know the mushroom cultivation technology for additional source of income. Same trend of result was obtained by Shahi et al., (2018) who found that $75.25 \%$ of the respondents were interested to learn the technology for additional source of income. Lesser participants were interested to learn the 
technology only to know the nutritional and medicinal value of mushroom (33\%) and to transfer the technology among the fellow farmers $(43 \%)$. Similar results were also reported by Kaur, 2016.

\section{Impact of training in terms of knowledge gained on selected mushroom production practice}

The change in the perception level of the participants about mushroom cultivation before and after the training programmes was shown in Table 3 . In most of the aspects the pre training knowledge was not much satisfactory except the knowledge on the substrate of mushroom from cereal crops in which $73.33 \%$ trainees had proper knowledge. In some of the aspects like poisonous chemical present in Amanita phalloides, method of pasteurization using fumigants, contaminants on substrate, common weeds in oyster mushroom, chemicals responsible for yellowing and method of blanching, none of the respondents made the correct answer. However, the knowledge score after training was found satisfactory in most of the aspects. Post training evaluation showed that more than 80 per cent respondents had correct knowledge on 32 numbers of practices. Regarding 3 practices viz. poisonous chemical present in Amanita phalloides, method of blanching and chemicals responsible for yellowing of mushroom during storage, 71 to 78 per cent respondents had adequate knowledge after the training programme. In the aspects like name of the edible mushroom other than oyster mushroom, name of the substrate of oyster mushroom from cereal crop, substrate from oil seed crop, pasteurization of substrate by boiling and method of sun drying all the participants gave appropriate answer. The reason behind the satisfactory performance after the training in regards to gain in knowledge may be due to the educational background of the trainees, interest on mushroom cultivation and the method followed during the programme (Shahi et al., 2018).

\section{Distribution of respondents according to their level of knowledge}

Respondents were grouped into low, medium and high category based on the level of knowledge on different aspects of oyster mushroom cultivation in pre and post training evaluation. It was evident from the Table 4 that 50 per cent of the respondents had low level of knowledge and rest 50 per cent had medium level of knowledge on recommended mushroom production practices during pre training period. However, after the intervention, all the respondents were found to gain the knowledge up to medium $(58.33 \%)$ and high level (48.67\%). The calculated value of ' $t$ ' (52.53) indicated that there was significantly higher level of knowledge in post training period as compared to the pre training period (Table 4). Lower level of Knowledge during pre training period may be due to lack of awareness about mushroom cultivation among the farmers in the district. Shifting of level of knowledge from lower to medium and high level during post training period indicated the effectiveness of the training and demonstration programme undertaken by Krishi Vigyan Kendra. Similar findings were also reported by Sohal and Fulzele (1986), Babu and Singh (1986), Sanadhya et al., (2002) and Sarma et al., (2014) who revealed that training and demonstrations were effective in terms of increasing the existing knowledge of participants about different agricultural aspects.

\section{Association of independent variables with knowledge gained by the respondents}

The participants of the training and demonstration programme scored differently due to their varied socio economic factors. 
Table.1 Socio economic profile of the respondents

\begin{tabular}{|c|c|c|}
\hline Sl. No. & Variables & Frequency(Percentage) \\
\hline 1. & $\begin{array}{l}\text { Age } \\
\text { Young (18-30) } \\
\text { Middle (31-50) } \\
\text { Old }(>51)\end{array}$ & $\begin{array}{l}34(56.67) \\
18(30.00) \\
8(13.33)\end{array}$ \\
\hline 2. & $\begin{array}{l}\text { Educational qualification } \\
\text { Illiterate(0) } \\
\text { Completed Primary Education(1) } \\
\text { Completed Middle School Education(2) } \\
\text { Matriculate(3) } \\
\text { Higher Secondary(4) } \\
\text { Graduation and above(5) }\end{array}$ & $\begin{array}{l}0(0) \\
5(8.33) \\
17(28.33) \\
20(33.33) \\
12(20.00) \\
6(10.00)\end{array}$ \\
\hline 3. & $\begin{array}{l}\text { Occupation } \\
\text { Farming (1) } \\
\text { Government service (2) } \\
\text { Businessman (3) } \\
\text { Others (daily labourers, rickshaw pullers etc.) }\end{array}$ & $\begin{array}{l}54(90.00) \\
1(1.67) \\
2(3.33) \\
3(5.00)\end{array}$ \\
\hline 4. & $\begin{array}{l}\text { Family type } \\
\text { Nucleus(1) } \\
\text { Joint(2) }\end{array}$ & $\begin{array}{l}56(93.33) \\
4(6.67)\end{array}$ \\
\hline 5. & $\begin{array}{l}\text { Experience in farming } \\
1-5 \text { years }(1) \\
6-10 \text { years }(2) \\
>11 \text { years }(3)\end{array}$ & $\begin{array}{l}33(55.00) \\
20(33.33) \\
7(11.67)\end{array}$ \\
\hline 6. & $\begin{array}{l}\text { Source of information about farming } \\
\text { Extension personnel (1) } \\
\text { Progressive farmers / Fellow farmers(2) } \\
\text { Input dealers ( } 3 \text { ) } \\
\text { Newspaper /Radio/TV(4) }\end{array}$ & $\begin{array}{l}12(20.00) \\
26(43.00) \\
20(33.33) \\
2(3.33)\end{array}$ \\
\hline 7. & $\begin{array}{l}\text { Farm size } \\
\text { Landless }(1) \\
\text { Marginal }(<1 \text { ha })(2) \\
\text { Small }(1-2 \text { ha })(3) \\
\text { Medium }(3-10 \text { ha)(4) } \\
\text { Large }(>10 \text { ha })(5)\end{array}$ & $\begin{array}{l}0(0.00) \\
41(68.33) \\
12(20.00) \\
7(11.67) \\
0(0.00)\end{array}$ \\
\hline
\end{tabular}

Table.2 Frequency and percentage distribution of respondents according to their stated reasons for participating in training and demonstration programme on oyster mushroom cultivation

\begin{tabular}{|l|l|c|c|}
\hline $\begin{array}{c}\text { Sl. } \\
\text { No. }\end{array}$ & \multicolumn{1}{|c|}{ Reasons for participation } & Number & Percentage \\
\hline $\mathbf{1 .}$ & To establish oyster mushroom farm for primary source of income & 76 & 25.33 \\
\hline $\mathbf{2 .}$ & To know the cultivation technology for additional source of income & 247 & 82.33 \\
\hline $\mathbf{3 .}$ & To know the cultivation technology for home consumption & 300 & 100.0 \\
\hline $\mathbf{4 .}$ & To know the nutritional value and medicinal property of mushroom & 33 & 11.00 \\
\hline $\mathbf{5 .}$ & $\begin{array}{l}\text { To get the certificate of training programme for receiving financial assistance } \\
\text { from bank }\end{array}$ & 62 & 20.67 \\
\hline $\mathbf{6 .}$ & For establishing good relationship with Krishi Vigyan Kendra & 211 & 70.33 \\
\hline $\mathbf{7 .}$ & $\begin{array}{l}\text { To acquire the knowledge and develop the skill for transferring the } \\
\text { technology among farmers }\end{array}$ & 43 & 14.33 \\
\hline
\end{tabular}


Table.3 Frequency and percentage distribution of respondents according to their knowledge level on oyster mushroom cultivation practices

\begin{tabular}{|c|c|c|c|}
\hline \multirow{2}{*}{$\begin{array}{l}\text { Sl. } \\
\text { No. }\end{array}$} & \multirow[t]{2}{*}{ Knowledge item of practice } & \multicolumn{2}{|c|}{ Frequency and Percentage } \\
\hline & & $\begin{array}{l}\text { Before } \\
\text { training } \\
(\mathrm{n}=60)\end{array}$ & $\begin{array}{l}\text { After training } \\
\quad(\mathbf{n}=60)\end{array}$ \\
\hline 1. & $\begin{array}{l}\text { Range of protein content of different oyster mushroom on dry weight } \\
\text { basis }\end{array}$ & $7(11.67)$ & $56(93.33)$ \\
\hline 2. & One important vitamin present in the oyster mushroom & $12(20.0)$ & $58(96.67)$ \\
\hline 3. & One important mineral present in the oyster mushroom & $5(8.33)$ & $51(85.0)$ \\
\hline 4. & Sugar content of oyster mushroom & $3(5.0)$ & $48(80.0)$ \\
\hline 5. & $\begin{array}{l}\text { Name one human disease against which oyster mushroom can be } \\
\text { used as health food }\end{array}$ & $23(38.33)$ & $56(93.33)$ \\
\hline 6. & Name of an edible mushroom other than oyster mushroom & $18(30.0)$ & $60(100)$ \\
\hline 7. & Name of a medicinal mushroom & $4(6.67)$ & $51(85.0)$ \\
\hline 8. & One important difference between edible and poisonous mushroom & $11(8.33)$ & $57(95.0)$ \\
\hline 9. & Name of the poisonous chemical present in Amanita phalloides & $0(0.0)$ & 43 (71.67) \\
\hline 10. & Name one superstition related to identification of edible mushroom & $2(3.33)$ & 55 (91.67) \\
\hline 11. & Principal composition of substrate of oyster mushroom & $6(10.0)$ & $49(81.67)$ \\
\hline 12. & Name one important substrate for oyster mushroom from cereal crops & $44(73.33)$ & $60(100)$ \\
\hline 13. & $\begin{array}{l}\text { Name one important substrate for oyster mushroom from oil seed } \\
\text { crops }\end{array}$ & $27(45.0)$ & $60(100)$ \\
\hline 14. & Name one important substrate for oyster mushroom from fiber crops & $2(3.33)$ & $51(85.0)$ \\
\hline 15. & $\begin{array}{l}\text { Name one important substrate for oyster mushroom from the waste } \\
\text { other than crop residues }\end{array}$ & $3(5.0)$ & $51(85.0)$ \\
\hline 16. & Method of pasteurization of substrate by boiling the straw & $11(18.33)$ & $60(100)$ \\
\hline 17. & Method of pasteurization of substrate by steaming the straw & $7(11.67)$ & $54(90.0)$ \\
\hline 18. & Method of pasteurization of substrate by using fungicide & $2(3.33)$ & $54(90.0)$ \\
\hline 19. & Method of pasteurization of substrate by using fumigants & $0(0.0)$ & $53(88.33)$ \\
\hline 20. & $\begin{array}{l}\text { Name of one contaminant generally occurs in the oyster mushroom } \\
\text { substrate }\end{array}$ & $0(0.0)$ & $56(93.33)$ \\
\hline 21. & Name of a weed which occurs in the substrate of oyster mushroom & $0(0.0)$ & 47 (78.33) \\
\hline 22. & Name of a fungal disease of oyster mushroom & $1(1.67)$ & $51(85.0)$ \\
\hline 23. & $\begin{array}{l}\text { Name of an insect pest generally infested in the oyster mushroom } \\
\text { fruiting body }\end{array}$ & $3(5.0)$ & $53(\mathbf{8 8 . 3 3})$ \\
\hline 24. & Precaution to avoid weed grown in oyster mushroom substrate & $7(11.67)$ & $50(83,33)$ \\
\hline 25. & Name one fungicide used against fungal disease of oyster mushroom & $17(28.33)$ & $57(95.0)$ \\
\hline 26. & Suitable range of temperature for growing oyster mushroom & $22(36.67)$ & $56(93.33)$ \\
\hline 27. & Number of days required for spawn running of oyster mushroom & $4(6.67)$ & $57(95.0)$ \\
\hline 28. & $\begin{array}{l}\text { Number of days required for sowing of spawn to pinhead formation } \\
\text { of oyster mushroom }\end{array}$ & $6(10.0)$ & $53(88.33)$ \\
\hline 29. & $\begin{array}{l}\text { Number of days required from pinhead formation to maturity of } \\
\text { oyster mushroom }\end{array}$ & $4(6.67)$ & $51(85.0)$ \\
\hline 30. & Major indication of maturity of fruiting body of oyster mushroom & $11(18.33)$ & $58(96.67)$ \\
\hline 31. & Method of sun drying of oyster mushroom & $24(40.0)$ & $60(100)$ \\
\hline 32. & Ideal packaging materials for fresh oyster mushroom & $4(6.67)$ & $53(88.33)$ \\
\hline 33. & Ideal temperature for storage of fresh oyster mushroom & $20(33.33)$ & $58(96.67)$ \\
\hline 34. & Chemical responsible for yellowing of mushroom during storage & $0(0.0)$ & 47 (78.33) \\
\hline 35. & Method of blanching of oyster mushroom & $\mathbf{0}(\mathbf{0 . 0})$ & $51(85.0)$ \\
\hline
\end{tabular}


Table.4 Distribution of respondents according to knowledge gained on mushroom cultivation

\begin{tabular}{|c|c|c|c|c|c|c|c|c|c|c|}
\hline \multirow[t]{2}{*}{ Category } & \multirow{2}{*}{$\begin{array}{l}\text { Score } \\
\text { range }\end{array}$} & \multicolumn{4}{|c|}{ Before $(n=60)$} & \multicolumn{4}{|c|}{ After $(n=60)$} & \multirow{2}{*}{$\begin{array}{c}\text { 't' } \\
\text { value }\end{array}$} \\
\hline & & $\begin{array}{c}\text { Frequency } \\
\& \\
\text { Percentage }\end{array}$ & $\begin{array}{c}\text { Mean } \\
\text { score }\end{array}$ & S.D. & C.V. & $\begin{array}{l}\text { Frequency } \\
\quad \& \\
\text { Percentage }\end{array}$ & $\begin{array}{l}\text { Mean } \\
\text { score }\end{array}$ & S.D. & C.V. & \\
\hline Low & $0-5$ & $30(50.00)$ & & & & $0(0.00)$ & & & & \\
\hline Medium & $5-32$ & $30(50.00)$ & 5.17 & 3.54 & 68.47 & $35(58.33)$ & 31.25 & 1.73 & 5.54 & $52.53 * *$ \\
\hline High & $32-35$ & $0(0.00)$ & & & & 25 (41.67) & & & & \\
\hline
\end{tabular}

* Significant at 0.05 level of probability

** Significant at 0.01 level of probability

Table.5 Relationship between a set of selected independent variables with knowledge gained by the respondents

\begin{tabular}{|c|l|c|c|}
\hline Sl. No. & \multicolumn{1}{|c|}{ Variables } & \multicolumn{2}{|c|}{ Knowledge gained } \\
\cline { 3 - 4 } & & 'r' value & 'P' value \\
\hline $\mathbf{1 .}$ & Age & 0.25 & $\mathbf{0 . 0 5 3}$ \\
\hline $\mathbf{2 .}$ & Education & $0.35^{*}$ & $\mathbf{0 . 0 0 6}$ \\
\hline $\mathbf{3 .}$ & Occupation & 0.03 & $\mathbf{0 . 7 9 3}$ \\
\hline $\mathbf{4 .}$ & Family type & 0.21 & $\mathbf{0 . 0 9 7}$ \\
\hline $\mathbf{5 .}$ & Experience in farming & 0.23 & $\mathbf{0 . 0 7 3}$ \\
\hline $\mathbf{6 .}$ & Source of information about farming & 0.12 & $\mathbf{0 . 3 7 7}$ \\
\hline $\mathbf{7 .}$ & Operational Land holding & $\mathbf{0 . 0 9}$ & $\mathbf{0 . 4 6 6}$ \\
\hline
\end{tabular}

* Significant at 0.05 level probability

** Significant at 0.01 level probability

Table.6 Constraints faced by the mushroom growers of Barpeta district of Assam and distributions according to the rank

\begin{tabular}{|c|c|c|c|c|}
\hline $\begin{array}{l}\text { Sl. } \\
\text { No. }\end{array}$ & Constraints & Frequency & Percentage & Rank \\
\hline 1. & $\begin{array}{l}\text { Lack of supply of the mushroom spawns according to } \\
\text { the demand of the growers }\end{array}$ & 55 & 91.67 & I \\
\hline 2. & $\begin{array}{l}\text { Lack of organized markets for selling the fresh oyster } \\
\text { mushroom }\end{array}$ & 32 & 53.33 & V \\
\hline 3. & $\begin{array}{l}\text { Lack of low cost low cost driers for drying the } \\
\text { mushroom }\end{array}$ & 26 & 43.33 & VII \\
\hline 4. & Lack of low cost high quality packaging technology & 36 & 60.00 & IV \\
\hline 5. & $\begin{array}{l}\text { Lack of financial facilities from banks for mushroom } \\
\text { entrepreneurs }\end{array}$ & 49 & 81.67 & II \\
\hline 6. & $\begin{array}{l}\text { Higher incidence of insects pests in summer oyster } \\
\text { mushroom }\end{array}$ & 31 & 51.67 & VI \\
\hline 7. & $\begin{array}{l}\text { Higher incidence of green mold contamination in } \\
\text { mushroom beds }\end{array}$ & 42 & 70.00 & III \\
\hline
\end{tabular}


The relationship between the knowledge gained with selected independent variables was assessed by using the Pearson's Product Moment Correlation Coefficient (Table 5). The findings revealed the non significant positive correlation between knowledge gained with the variables like age, occupation, family type, experience in farming, source of information about farming and operational land holding. However, significant positive correlation was observed $(\mathrm{r}=35)$ between education of the respondents with knowledge gained during the training programme. The positive and significant correlation indicates that the participants with higher level of education had better knowledge gain. The above finding was in conformity with the findings of Rachna et al., (2013).

\section{Constraints faced by the mushroom growers in adopting recommended practices}

Multiple responses were taken to find out the constraints faced by mushroom growers in Barpeta district of Assam. The findings (Table 6) revealed that among several constraints, the highest percentage of the respondents $(91.67 \%)$ reported that lack of supply of mushroom spawn according to demand as the main constraint and ranked I, followed by lack of financial facilities from bank for mushroom entrepreneurs (81.67\%) and ranked II, higher incidence of green mould in mushroom bed (70\%) and ranked III, lack of low cost quality packaging material (60\%) and ranked IV, lack of organized market for fresh oyster mushroom (53.33\% and ranked $\mathrm{V}$, higher incidence of insect pests in summer oyster mushroom (51.67\%) and ranked VI and lack of low cost driers $(43.33 \%)$ and ranked VII.

Shirur et al., (2016) also documented the constraints faced by the mushroom growers in Belagavi district of Karnataka like non- availability of spawn, lack of technical information and exploitation by consultants, increasing labour wages and higher cost on electricity etc. Similarly Bashar (2006) also reported the higher price of mushroom spawn was one of the major constraints faced by the mushroom growers.

The present study concludes that training and demonstration are essential to increase the knowledge level of the farmers for successful adoption of novel agricultural technology. The educational qualification may be considered while selecting the trainees for adoption of technology which needs scientific skill like mushroom cultivation. The constraints faced by the adopters of a new technology must be evaluated for greater horizontal spread. In our present study, lack of supply of mushroom spawn was found to be the major constraint faced by the adopters which can be overcome by increasing the vocational training on mushroom spawn production technology.

\section{References}

Babu, A.R. and Singh, R.P. (1986). Training young farmers towards manpower development in agriculture. Indian $J$. Extn. Edn. XXII(3-4): 48-53.

Bashar, M.A. (2006). Problem confrontation of the farmers in mushroom cultivation. Unpublished M.Sc. Thesis. Department of Agricultural Extension and Information System. Sher-e-Bangla Agricultural University, Dhaka.

Dasgupta, I. (1989). Diffusion of agricultural innovation in village India. Wiley Eastern Ltd., New Delhi.

Kaur, K. (2016). Impact of training course on knowledge gain of mushroom trainees. J Krishi Vigyan. 4(2): 54-57.

Leihaothabam, N.S., Singh, A.T., Stina, K., Singh, M.S., Singh, R.S., Vivekananda, Y and Shyamananda, K.C. (2020). A 
Study on Training Needs Assessment of Rice Growing Farmers in Imphal East District, Manipur, India. Int.J.Curr.Microbiol.App.Sci. 9(3): 6674.

Rachna, R.G. and Sodhi, G.P.S. (2013). Evaluation of Vocational Training Programmes organized on Mushroom Farming by Krishi Vigyan Kendra Patiala. J.Krishi Vigyan 2(1): 26-29.

Sanadhya, M., Solanki, D. and Dashora, P.K. (2002). Impact assessment of training on technologies for women. Agric. Extn. Rev. 14(2): 7-9.

Sarma, H., Sarma, R., Sarmah, A.K., Upamanya, G.K. and Kalita, N. (2014). Yield gap analysis of toria (Brassica campestris) in Barpeta district of Assam. Indian Res. J. Ext. Edu. 14 (2): 131-133.

Sarma, H., Talukdar, R.K., and Mishra, P. (2013). Impact of Training in Terms of Level of Knowledge Enhanced on Integrated Rice-Fish Farming Practices. Indian Res. J. Ext. Edu. 13 (1): 35-38

Shahi, V., Shahi, B., Kumar, V., Singh, K.M. and Kumar, P. (2018). Impact study on mushroom cultivation for micro entrepreneurship development and women Empowerment. Journal of Pharmacognosy and Phytochemistry.
SP4: 01-04.

Shirur, M., Shivalinge G., Chandregowda, N.S., Sunil, M.J. and Rana, R.K. (2017). An exemplary story of growing temperate mushroom in tropical climate of rural India: Lessons for other startups. Int. J. Curr. Microbiol. App. Sci., 6 (9): 2423-2433.

Singh, S. and Singh, A. (2014). Status and scope of mushroom cultivation in Haryana constraints and future outlook. Proceedings of the 8th International Conference on Mushroom Biology and Mushroom Products. Pp 612- 614.

Singh, V., Suryawanshi, D.K., Khan, M.A. and Ahirwar, L. (2020). Constraints perceived by the beneficiaries of chickpea growers families in NFSM programme in Chhattisgarh state. Journal of Pharmacognosy and Phytochemistry. 9(1): 411-413

Sohal, T.S. and Fulzele, R.M. (1986). Training for HRD. Indian J. Extn. Edn. XXII (3\&4): 38-40.

Upamanya G.K. and Sarma, H., Sarmah A.K. (2019). Knowledge level of Village Level Extension Workers on Biocontrol Agents and biopesticides in Barpeta district of Assam IARJSET. 6(12): 5658.

\section{How to cite this article:}

Upamanya, G.K., Haridra Sarma, P.D. Barman and Deka, A.K. 2020. Evaluation of Training Programmes on Oyster Mushroom Cultivation Conducted by KVK, Barpeta and Constraints Perceived by Mushroom Growers in Barpeta District of Assam, India. Int.J.Curr.Microbiol.App.Sci. 9(05): 560-568. doi: https://doi.org/10.20546/ijcmas.2020.905.063 